\title{
PENGARUH MOTIVASI TERHADAP KINERJA KARYAWAN
}

\author{
Viola De Yusa ${ }^{1)}$ \\ Andika Rananda ${ }^{1)}$ \\ 1) Institut Informatika dan Bisnis Darmajaya, Lampung \\ viola.d.yusa@gmail.com , andikarananda16@gmail.com
}

\begin{abstract}
ABSTRAK: Tujuan penelitian ini adalah untuk mengetahui pengaruh motivasi terhadap kinerja karyawan di PT Sumber Trada Motor Bandar Lampung. Penelitian ini merupakan jenis penelitian kuantitatif dengan metode penelitian asosiatif. Penelitian ini dilakukan di PT Sumber Trada Motor Bandar Lampung. Teknik pengambilan sampel menggunakan teknik sampel jenuh dan metode analisis data menggunakan regresi linier sederhana dan pengujian hipotesis menggunakan uji t. Responden dalam penelitian ini sebanyak 36 karyawan. Uji persyaratan instrumen dalam penelitian ini menggunakan uji validitas dan uji reliabilitas. Motivasi kerja berpengaruh terhadap Kinerja. Artinya semakin baik motivasi diberikan kepada karyawan maka semakin tinggi pula tingkat kinerja karyawan pada perusahaan.
\end{abstract}

Kata kunci : Motivasi, Kinerja Karyawan.

ABSTRACT: The purpose of this study was to determine the effect of motivation on employee performance at PT Sumber Trada Motor Bandar Lampung. This research is a type of quantitative research with associative research methods. This research was conducted at PT Sumber Trada Motor Bandar Lampung. The sampling technique uses saturated sample techniques and data analysis methods using simple linear regression and hypothesis testing using the $t$ test. Respondents in this study were 36 employees. Test the instrument requirements in this study using validity test and reliability test. Work motivation affects performance. This means that the better motivation is given to employees, the higher the level of employee performance at the company. Keywords: Motivasion, Employee Performance.

\section{PENDAHULUAN}

Keberhasilan ataupun kegagalan suatu organisasi atau perusahaan melaksanakan tugas dan fungsinya sangat berhubungan erat dengan pelaku-pelaku organisasi tersebut, atau dengan kata lain sumber daya manusia mempunyai peran strategis sebagai penentu berhasil tidaknya pencapaian kinerja dalam suatu organisasi. Sumber Daya Manusia (SDM) adalah faktor central dalam suatu organisasi. Apapun bentuk serta tujuannya, organisasi dibuat berdasarkan berbagai visi untuk kepentingan manusia dan dalam pelaksanaan misinya dikelola dan diurus oleh manusia. Jadi, manusia merupakan faktor strategis dalam semua kegiatan organisasi. PT Sumber Trada Motor adalah perusahaan yang bergerak dibidang kendaraan roda dua dengan merek Kawasaki. Perusahaan ini merupakan satu satunya dealer yang ada di kota Bandar Lampung yang memiliki 3 cabang dealer. Perusahaan ini dipercaya bisa menjual produk kawasaki diwilayah Bandar Lampung. 
Kinerja karyawan pada perusahaan merupakan fondasi dasar yang harus dibangun, dijaga dan di kembangkan dalam perusahaan agar memberikan dampak yang positif bagi perusahaan baik dalam kualitas maupun kuantitasnya. Kinerja yang lebih tinggi mengandung arti terjadinya peningkatan efisiensi, efektifitas, atau kualitas yang lebih tinggi dari penyelesaian serangkaian tugas yang dibebankan kepada seorang karyawan dalam suatu organisasi atau perusahaan. Dari hasil penilaian kinerja yang dilakukan oleh PT Sumber Trada Motor Bandar Lampung diketahui bahwa kinerja karyawan berada pada kriteria kurang baik. Hasil ini belum memenuhi harapan perusahaan dimana kriteria kinerja perusahaan paling tidak berada dalam kriteria baik. Penilaian terhadap kinerja dapat mengetahui sejauh mana karyawan itu dapat melaksanakan tugasnya dengan baik. Penilaian kinerja di PT Sumber Trada Motor Bandar Lampung dilakukan pada setiap tahunnya. Kinerja selama satu tahun menunjukan ratarata target kinerja karyawan secara keseluruhan hanya mencapai $63,97 \%$, nilai tersebut memiliki kriteria nilai Kurang Baik.

Motivasi menjadi salah satu yang mempengaruhi kinerja karyawan. Motivasi merupakan dorongan terhadap serangkaian proses prilaku manusia pada pencapaian tujuan. Menurut Veithzal Rivai (2011, p.837), mendifinisikan bahwa motivasi adalah serangkaian sikap dan nilai-nilai yang mempengaruhi individu tuntuk mencapai hal yang spesifik sesuai dengan tujuan individu. . Pemberian motivasi kerja yang telah dilakukan oleh PT. Sumber Trada Motor kepada karyawannya adalah dengan memberikan motivasi kerja berupa pemberian insentif pada karyawan yang mencapai target yang di tetapkan perusahaan dan memberikan jenjang karir pada pekerjaannya. Dalam penerapannya masih saja terdapat masalah motivasi kerja yang terjadi pada karyawan dalam menjalankan tugasnya, masih ada beberapa masalah terkait motivasi kerja yang dialami oleh karyawan PT. Sumber Trada Motor yaitu kurangnya tanggung jawab dari karyawan dalam menjalankan pekerjaannya. Rendahnya tingkat inisiatif dan usaha untuk menyelesaikan pekerjaannya terbukti dengan adanya beberapa karyawan yang tidak menyelesaikan pekerjaannya sesuai batas waktu yang telah ditentukan oleh perusahaan. Hal tersebut pula yang akhirnya menyebabkan penilaian kinerja karyawan yang masih dalam kriteria kurang baik.

\section{METODE PENELITIAN}

Penelitian ini yang di ukur adalah variabel (X) Motivasi Kerja, dan variabel (Y) yaitu Kinerja. Uji persyaratan instrument penelitian menguji validitas dan reliabilitas. Populasi penelitian sebanyak 36 responden yang akan dibagikan kepada karyawan PT Sumber Trada Motor Bandar Lampung. Alat analisis yang digunakan dalam penelitian adalah regresi linier sederhana. 


\section{HASIL DAN PEMBAHASAN}

\section{Hasil Uji Validitas}

Hasil uji validitas variabel motivasi (X) dengan menampilkan seluruh item pernyataan yang bersangkutan mengenai motivasi. Hasil yang didapatkan yaitu nilai rhitung lebih besar dari $r_{\text {tabel }}(0.329)$, dimana nilai $r_{\text {hitung }}$ paling tinggi yaitu 0,752 dan paling rendah 0,461 . Dengan demikian seluruh item pernyataan motivasi dinyatakanvalid.

Hasil uji validitas variabel kinerja karyawan (Y) dengan menampilkan seluruh item pernyataan yang bersangkutan mengenai kinerja karyawan. Hasil yang didapatkan yaitu nilai $r_{\text {hitung }}$ lebih besar dari $r_{\text {tabel }}(0.329)$, dimana nilai $r_{\text {hitung }}$ paling tinggi yaitu 0,829 dan paling rendah 0,506. Dengan demikian seluruh item kinerja karyawan dinyatakan valid.

\section{Hasil Uji Reliabilitas}

Berdasarkan hasil uji reliabilitas nilai cronbach's alpha sebesar 0,758 untuk variabel motivasi $(\mathrm{X})$ dengan tingkat reliabel tinggi, dan 0,894 untuk variabel kinerja (Y) dengan tingkat reliabel sangat tinggi.

\section{Hasil Uji Regresi Sederhana}

Tabel 1. Hasil Uji Regresi Linier Sederhana

\begin{tabular}{cc}
\hline Nilai Korelasi $(\mathbf{R})$ & R Square $\left(\mathbf{R}^{\mathbf{2}}\right)$ \\
\hline 0,363 & 0,132
\end{tabular}

Sumber: Hasil data diolah tahun 2018

Pada tabel 1 diperoleh nilai koefisien determinasinya (R Squares) sebesar 0,132 menunjukan bahwa Kinerja (Y) dipengaruhi Motivasi Kerja (X) sebesar 13,2\% sedangkan $86,8 \%$ di pengaruhi oleh faktor/variabel lain. Hubungan Motivasi Kerja (X) terhadap Kinerja (Y) adalah sebesar 0,363, hasil ini menunjukan hubungan yang cukup/sedang antara variabel Motivasi Kerja (X) terhadap Kinerja (Y).

Tabel 2. Hasil Uji Koefisien Regresi

\begin{tabular}{lcc}
\hline & B & Std.Error \\
\hline $\begin{array}{l}\text { Konstanta } \\
\text { (Kinerja) }\end{array}$ & 23,678 & 6,369 \\
\hline Motivasi & 0,478 & 0,210 \\
\hline Sumber: Hasil data diolah tahun 2018 &
\end{tabular}

Persamaan regresinya sebagai berikut :

$$
\begin{aligned}
& Y=a+b X \\
& Y=23,678+0,478
\end{aligned}
$$


Keterangan :

$\mathrm{Y} \quad=$ Keputusan Pembelian

a $\quad=$ konstanta

$\mathrm{b} \quad=$ koefisien regresi

Persamaan regresi di atas dapat dijelaskan sebagai berikut:

1 Konstanta sebesar 23,678 artinya jika Motivasi Kerja (X) nilainya adalah 0, Kinerja nilainya adalah 23,678.

2 Koefisien regresi untuk variabel Motivasi (X) sebesar 0,478 menyatakan bahwa setiap penambahan sebesar satu satuan X (Motivasi) maka akan menurunkan Kinerja sebesar 0,478. Koefisien bernilai positif artinya terjadi hubungan positif antara Motivasi dengan Kinerja, semakin besar pengaruh Motivasi maka semakin meningkat Kinerja Karyawan.

\section{Hasil Uji t}

Tabel 3

Koefisien Regresi Motivasi Kerja (X) dan Kinerja (Y)

\begin{tabular}{ccc}
\hline Motivasi & $t_{\text {hitung }}$ & Sig \\
$(\mathrm{X} 2)$ & 2,272 & 0,030
\end{tabular}

Sumber : Hasil data diolah tahun 2018

Terlihat bahwa $t_{\text {hitung }}$ sebesar 2,272 sedangkan ttabel dengan dk (36-2) adalah 2,032. Jadi $t_{\text {hitung }}(2,272)>t_{\text {tabel }}$ (2,032). Dengan demikian Ho ditolak dan Ha diterima. Kesimpulannya Motivasi Kerja berpengaruh terhadap Kinerja karyawan PT Sumber Trada Motor Bandar Lampung.

\section{PEMBAHASAN}

Hasil analisis regresi membuktikan bahwa secara parsial terdapat pengaruh dari motivasi kerja terhadap kinerja karyawan. Motivasi merupakan dorongan yang menjadi sebab seseorang melakukan suatu perbuatan/kegiatan, artinya karyawan yang mempunyai motivasi tinggi maka karyawan tersebut dapat menjalankan tugasnya dengan sangat baik sehingga kinerja pun akan tinggi sebaliknya ketika karyawan memiliki motivasi yang rendah maka kinerjanya pun akan rendah. Sahanggamu (2014) mengatakan bahwa semakin banyak motivasi yang diberikan kepada karyawan sangat berpengaruh untuk meningkatkan kinerja karyawan. Hal ini sejalan dengan penelitian yang dilakukan oleh Nugroho (2017) yang menyatakan bahwa motivasi mempunyai pengaruh dominan terhadap kinerja karyawan pada PT Bank Danamon Devisi SEMM Area Ngawi. Hal ini 
menunjukkan semakin tinggi motivasi semakin tinggi pula kinerja karyawan dan karyawan yang termotivasi dengan baik dapat menunjukkan kinerja kearah yang lebih baik.

\section{KESIMPULAN}

Berdasarkan analisis data dan tujuan penelitian pada bab sebelumnya maka dapat disimpulkan bahwa motivasi kerja berpengaruh terhadap Kinerja karyawan PT Sumber Trada Motor Bandar Lampung.

\section{DAFTAR PUSTAKA}

Aprilia, Echa Siska. 2017. Pengaruh Kompensasi dan Motivasi Kerja Terhadap Kinerja Karyawan Pada Bank Syariah Mandiri. Fakultas Ekonomi dan Bisnis Islam. Uin Raden Fatah, Palembang.

Arikunto, S. 2016. Prosedur Penelitian. Pt. Rineka Cipta, Jakarta.

Bangun, Wilson. 2012. Manajemen Sumber Daya Manusia. Erlangga, Jakarta.

Darmajaya, IIB. 2016. Panduan Penyusunan Karya Ilmiah. Jurusan Manajemen,

Bandar Lampung.

Hasibuan, Malayu S.P. 2016. Manajemen Sumber Daya Manusia. PT. Bumi Aksara, Jakarta.

Nugroho, Febriawan Ardi, Marsono, Misnan. 2017. Pengaruh Budaya Organisasi, Kepemimpinan Dan Motivasi Kerja Terhadap Kinerja Karyawan Pada Pt Bank Danamon Divisi Semm Area Ngawi. EKUILIBRIUM : Jurnal Bidang Ilmu Ekonomi Vol. 12 No 2 (2017): Hal. 119-124.

Oktawati, Desy. 2016. Pengaruh Kompensasi dan Motivasi Terhadap Kinerja Pegawai Pada Dinas Pendapatan Pengelolaan Keuangan dan Aset Daerah Kabupaten Sarolangun (DPPKAD). Program Pascasarjana. Universitas Terbuka, Sarolangun.

Priansa, Donni Juni. 2014. Perencanaan dan Pengembangan Sumber Daya Manusia. Alfabeta, Bandung.

Rivai, Veithzal. 2011. Manajemen Sumber Daya Manusia Untuk Perusahaan Dari Teori Ke Praktek. PT. Rajagrafindo Persada, Jakarta.

Sahanggamu, Patricia, M., dan Mandey Silvya, L. 2014. Pengaruh Pelatihan Kerja, Motivasi dan Disiplin Kerja Terhadap Kinerja Karyawan pada PT. Bank Perkreditan Rahyat Dana Raya. Jurnal EMBA. Vol.2 No 4:514-523.

Simamora, Henry. 2004. Manajemen Sumber Daya Mnausia. STIE YKPN, Yogyakarta.

Sinambela. Lijan Poltak. 2016. Manajemen Sumber Daya Manusia. PT Bumi Aksara, Jakarta. 
Sugiyono. 2010. Metode Penelitian Kuantitatif Kualitatif dan R\&D. Alfabeta, Bandung.

Sugiyono. 2016. Metode Penelitian Kuantitatif, Kualitatif, Dan R\&D. Alfabeta, Bandung.

Suwati, Yuli. 2013. Pengaruh Kompensasi dan Motivasi Kerja terhadap Kinerja Karyawan pada PT. Tunas Hijau Samarinda. Fakultas Ilmu Sosial dan Politik, Universitas Mulawarman, Samarinda.

Syahyuti. 2010. Definisi, Variabel, Indikator dan Pengukuran dalam Ilmu Sosial. Bina Rena Pariwara, Jakarta.

Wibowo. 2016. Manajemen Kinerja. PT Raja Grafindo Persada, Jakarta 